\title{
THE TEENEGERS' CHARACTERISTICS IN GENDER WRITTEN TEXT BY DISCOURSE ANALYSIS AT BATAM
}

\author{
Frangky Silitonga \\ Universitas Putera Batam \\ frangkyka@gmail.com
}

\begin{abstract}
This paper gives a clear picture of the differences and competence of teenagers in Batam on producing gender written texts. This article also analyzed short coherent paragraphs by two different gender groups: male and female groups. Discourse analysis was employed to analyze the data - two different pictures. The data of this qualitative research comprise words, clauses and sentences classified into nouns, verbs, adjectives and adverbs. The researcher focused on the characteristics of both genders in expressing their ideas; selfconfidence, doubt, language skills and logic. It is found that female students produced more words particularly nouns than those of males.
\end{abstract}

\begin{abstract}
Abstrak
Artikel ini memberikan gambaran secara jelas bagaimana perbedaan ciri dan kemampuan anak-anak remaja di Batam menghasilkan perbeaan kata-kata berdasarkan jenis kelamin. Antara wanita dan pria dianalisa ketika mereka menuangkan gagasan kedalam bentuk tulisan sehingga menjadi paragrap singkat yang koheren. Instrument yang digunakan dalam penelitian ini adalah wacana analisa bergambar, terdapat dua gambar yang berbeda. Dari gambar tersebut ditemukan data, tulisan yang dianalisis dengan menggunakan metodologi qualitative dan teori pendekatan dari sosiolinguistik. Data ini berupa kata, klausa, kalimat dihasilkan melalui kuesioner tersebut kemudian diklasifikasikan berdasarkan kelas kata, seperti kata benda, kata kerja, kata sifat, dan kata keterangan. Kemudian peneliti juga menetapkan bagian perbedaan secara karakteristik pada kedua jenis kelamin tersebut, dalam menuangkan gagasan, diantaranya rasa tidak percaya diri atau ragu-ragu dan merasa mampu atau masuk akal. Signifikansi banyaknya kata yang dihasilkan oleh pelajar SMA di Batam dasarkan jenis kelaminnya adalah wanita. Setelah menganalisa kedua gambar yang berbeda dari gambar yang pertama dan kedua dapat disimpulkan bahwa kecenderungan wanita mampu menghasilkan kelas kata benda ketika menuangkan gagasan kedalam paragrap daripada laki laki.
\end{abstract}

Kata Kunci: ciri, tulisan, jender, kelas kata, kalimat

\section{Introduction}

Language is a tool of communication. Language is also defined as the way for human being to communicate. Linguistics is scientific study about language. Linguistics is the field of the study that guides the people to learn about language including the pattern or form of the language itself and also the meaning of the language. Learning language means that people concerns with not only the forms and the meaning but also the relation of the language with the social life. Talking about language in social life, sociolinguistics is a term that 
concerns with language that has relation with social life. It means that language cannot be separated with social life. People are not able to build relationship with other people without language. Furthermore, language is the bridge for human being in the world, where people are able to communicate each other through language. In other words, language is important in human life to face the world. People have their own language to express their idea, feeling, experience, thought and so on. People can continue their life because of language as language is a means of communication amongst human being. I conclude that the language itself is not only a term that human being should learn but also language is part of human life.

Language has variety of function; it can be seen from the social groups or community. Besides, language is also defined not only a medium of communication - verbal communication. As asserted by Pardede and Kisno (2011, p.1), "in the way of language is communicated, it can be divided into three ways, such as spoken language, written language and gesture." The term spoken language refers to the speaker and listener where language is spoken in communication. The term written language refers to the writers and the readers where the language is written in communicating. The term gesture refers to the person that uses body movement in communication. Furthermore, in Sociolinguistics, language can also be identified based on the gender writing, where gender writing concerns with the ways to express language based on their gender (male and female). Here, the difference of gender will show how many words they used in speaking or written were based on what they see. This research is conducted to see the quantity of the words used by male and female students regarding the place such as at school and at home. Sometimes, people are most critical at their school with their second language.

In language use, the society has different ways to express their ideas, feeling, emotions, and experience. In society, parents, teenagers and students have different ways to express the language, for examples the stress, intonation and so on. Here, I am interested to investigate the ways of the students to express their language. What students are saying in delivering the message; in spoken and written to the receiver. Discussing writing, it can be defined "as the symbolic representation of language through the use of graphic sign" (Yule 2010, p.212). The author highlights that writing is the representation of the language based on what people see or thinking about something. Here, I want to see the ability of the students at school to write sentences through written discourse. Every research has the identification of the problem and in this article, I also have the identification of the problem coming from the ability of the students to write something through a picture. I identify the problem through three steps for instances quantity of words, word classes and characteristics used by the students in their ability to analyze a picture by writing on a paper. Some authors also have ideas regarding the writing gender. Yule is one of the authors that gives his idea about writing gender, and he said that there can be differences in the words used by men and women in variety of language (2010, p. 275). It means that men and women are different at their word choices. He also stated that women are more likely to use their high prestige form related to social status. Another fact that Yule mentioned in his book as quoted below.

The difference is most noticeable among middle-class speaker. in one double negative study (e.g. I don't want none) showed in lower-middle-class speech, substantially more men $(32 \%)$ than women $(1 \%)$ using the structure.

Furthermore, a natural first step in a scientific approach to words is to seek to establish the different types of words which appear in language (Radford and Adkinson, 2009). It means that by creating a sentence in English language, he or she is required to recognize the word classes in order to have a good sentence. Radford and Adkinson also affirmed that 
there are four types of words needed to recognize Noun, Verb, Adjective, and Adverb. On the other hand, the structures of the sentences produced by the participants are also part of this research issue. According to Stockwell (2006), there are some characteristics that can be used to recognize the sentence to describe the participants' characters. Here, I took two characters; (1) being weak, vulnerable or scared and (2) being strong, capable and logical. Additionally, I would like to show some examples of the gender-based writingwhich are done by myself, as follows;

a. In this photo I can see a man and a baby. They are at home, probably in the living room.

b. On the left we can see the man holding the baby with his right hand and vacuuming the carpet with his left hand.

c. The man is probably in his thirties. I am not sure because I can't see his face. The baby is very young, a few months only.

d. The man is wearing a pair of white socks, jeans, white T-shirt and dark red shirt.

e. The baby is wearing white nappies and rompers.

f. The man seems stressed and the baby seems shocked

g. The living room is untidy. There are a lot of things on the sofa and on the floor: toys, a teddy bear, cushions, a striped blanket. There is a picture on the wall

h. In my opinion, it is a very funny photo.

From the examples mentione, there are so many parts in Sociolinguistic that can be found in the descriptions above such as the characteristics of gender-based writing, lexical categories and the number of words production. It shows that the gender-based writing at school is an interesting object to be research.

Sociolinguistics is the term that concerns with the relation between language and social life. In Sociolinguistics, a relationship among people can be portrayed through the language. According to Stockwell (2002, p. 1), there are three elements in Sociolinguistics, all language events consist of a piece of language in a social context; every different social context determines that particular form of language; and the language used in particular situation determines the nature of that social event. Language users cannot be separated from their social life. It can be concluded that language is important in people's life especially in their communication. Because of language people can do anything with another; they can build their relationship and also they can be together or gathering.

Furthermore, in Sociolinguistics there are some things that influence people in continuing their life regarding the existence of language for instance social class, culture, and community. On the other hand, region also influences their communication ability with other people in their surroundings, particularly verbal communication. Regionally, there are some countries that have different ways within their spoken language, for instances America, United Kingdom, Australia, and Singapore. Therefore, in analyzing the language itself, I must see the region where the language is used.

Additionally, everybody does not use the same way of speaking language regarding geographical areas but not with social life that their way of speaking language can be seen. This is the reason of the certain used language such as slang or jargon that is more likely found in social life. Beside, education and knowledge are also influencing the way of speaking language. In society, if a person has high education and knowledge, automatically he or she has his or her own way of speaking language. Here, in this article, I would like to see the ability of the students through pictures. 


\section{Literature Review}

Conversation is the action between speaker and listener discussing something. In the conversation people speak each other out of planned and commonly it occurs naturally so each of them must give paid close attention to him or her who's speaking. The term conversation is a corporative activity in the sense that is involves two or more parties, each of whom must be allowed the opportunity to participate (Wardhaugh, 2006, p.298). It means that in a conversation both of them speaker and listener must be active in order to make the conversation alive. In conversation there is a term turn taking where turn taking in conversation is much more complex than it might appear because people engage in it so easily and skillfully. Conversation is not only happened in face to face but by phone people are able to build a conversation even it is shorter than face to face.

Furthermore, conversation is not only by speaking language but conversation can be done by written language or texts. It usually happens when people think that what they are going to be done is not really important and because of the time or place that might be impossible for them to speak face to face or by phone calling so here written or texts in written must be the appropriate way to reach them like email, letter by post, and so on. In conversation there are some advantages that people can take. By speaking language face to face, they can see each other physically their condition and be more active.

\subsection{Speech Community}

Speech community is not only defined by any marked agreement in the use of language elements, so much as by participation in a set of shared norms (Labove in Wardhaugh 2006, p.121). It means that people make a group become a speech community concerned with any aspect of the human being including language and norms. In the speech community, the people have their own way and style to express the language itself. As seen in society, each community is different and every person is not allowed to have two communities. In their way of speaking language, the different range of variations of their selves' speech community will be seen automatically because it will help them keep their secret and make them become confident.

Furthermore, according to Leonard, B (1973, p. 42), speech community is "a group of people who interact by means of speech." It means that speech community is established in order to help them carry out their creativities and their freedom to say something. The speech community itself will help the group member have confidence and each member is not allowed to judge another member for any mistakes. Speech community will also help the members respect a person within the weaknesses, having many friends.

\subsection{Gender}

Gender is another topic of Sociolinguistics that can be used as the main part in any of researche particularly language research. Gender is a unique lesson in Sociolinguistics that focuses on sex physically in order to see the relationship between language and social life. Gender concerns with men and women who use language. In gender, people are able to see different ways and styles in expressing the language between men and women. According to Wardhaugh (2006, p.316), "gender is something that people cannot avoid. It is part of the way in which societies are ordered around the people." The author also defines that gender is a key component of identity. The author highlights that gender is a term that is very important in the societies and help people recognize the identity of a person belonging to man or woman. The fact that can be seen in order help people to understand the differences between men and women which has been observed by Labove in Philadelphia says that women conform 
more closely than men to sociolinguistic norms that are overtly prescribed. However women conform less than men when they are not to read that men are less conforming than women with stable linguistic variables and more conforming when change is in progress within a linguistic system. So, based on the explanation above, it can be concluded that both men and women have their own way to express their ideas through language.

On the other hand, gender also defines as the sex different study which is not doing more than set out to find statistically significant differences between men's and women's behavior. It means that gender is the study of the human behavior in order to find out the statistical significances. Therefore, by taking gender as the main part in conducting a research, it means that I focus on the behavior of the men and women through language. From this analysis, I am able to see the characteristic of men and women. Here, there are five in setting out a list of what the author calls sociolinguistic universal tendencies (Holmen in Wardhaugh 2006, p. 322), they are;

a. Women and men develop different patterns of language use

b. Women tend to focus on the affective functions of an interaction more than men do

c. Women tend to use linguistic devices that stress solidarity more than men do

d. Women tend to interact in ways which will maintain and increase solidarity. While especially in formal contexts men tend to interact in ways which will maintain and increase their power and status

e. Women are statistically more flexible than men.

f. Those five lists show how men's and women's behavior carried out and as the result women are more likely active to express their ideas.

\subsection{Writing}

Writing is a skill of a person in writing something that requires constant practice. Writing is also a way in communication by producing words through ink on the paper. Writing is one of the skills in English subject besides speaking, reading, and listening. A good writing is a skill that must be understood and mastered (Belmont \& Sharkey, 2011, p.1). It means that a good writer is not only good at writing but he or she must understand and know well what he or she writes. Additionally, in writing there are some parts needed to consider such as grammar, lexical choice and so on. By concerning those considerations, they will help a person write especially in the grammatical and word choice.

Furthermore, writing is a flexible subject where the object is not limited. Everything can be written as long as the doer does not break the rules in writing. Picture is one of the objects on writing. This research will be conducted by focusing in gender in writing their opinion through a picture. I will concern with what gender writing is.

\subsection{Gender-Based Writing}

Writing is the symbolic representation of language through the use of graphic or sign. It means that people are able to represent language by using graphic or sign. Hence, gender-based writing is the representation of visualization by writing in a paper. genderbased writing is also defines as the ability of men or women to write down what they see. gender-based writing is "the study of exploring the different discursive strategies used by men and women" (Stokwell 2006, p.159). It means that gender-based writing is the way to see the differences of men's and women's strategies in writing (word choice and structure). Here there are guidelines for the representation of women and men in English language. These guidelines have been compiled as "a reminder to people involved in all aspects of ELT publishing to be aware of discriminatory language and stereotypes, images and whenever 
possible, to use inclusive language and image which reflect a more balanced and accurate view of the world of the present state of English" (Stokwell 2006, p. 84).

\section{- $\quad$ Avoiding stereotypes}

Avoiding stereotypes can be done much more to avoid presenting people in a stereotypes way.

\subsection{Characters}

Both men and women are shown in text, dialogues, recordings, and illustration. Here, there are some characters that could help people find out men and women characters in a text, dialogues, recordings as depicted below; Stockwell 2006, p. 85)

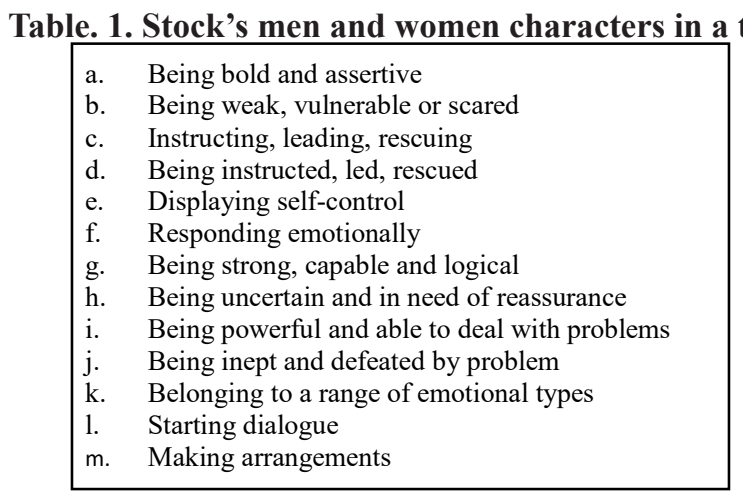

From those characters mentioned above, because of the limitation of time I will apply two of them. They are being weak, vulnerable or scared and being strong, capable and logical.

\subsubsection{Women in language}

As with stereotypes, language which excludes women can be dealt with two types, for instance by avoiding its use and by dealing sensitively with exclusive language that comes up in, for example, authentic recordings. In the second case, it is often enough to suggest that a teacher points out that a particular usage may offend many women and to ensure that other authentic recordings demonstrate inclusive language.

\subsubsection{False generic}

Studies of native English speaking college students and students have shown that generic use of words like man (ostensibly to include all humans), does not elicit mental images of both sexes.

\subsubsection{Avoiding false generic 'man'}

Furthermore, women and men are constructing their gender identity. Language is "the site of the culture production of gender identity" (Crawford in Stokwell, p. 160). Gender identity can be classified into two, they are;

Table. 2. Gender Identity

\begin{tabular}{ll}
\hline \multicolumn{1}{c}{ Instead of } & \multicolumn{1}{c}{ Use } \\
\hline Mankind & people, humans, humanity \\
Manpower & work force, staff \\
\hline
\end{tabular}




\begin{tabular}{ll}
\hline \multicolumn{1}{c}{ Instead of } & \multicolumn{1}{c}{ Use } \\
\hline Man-made & artificial, synthetic, manufactured \\
Man-to-man & person-to-person \\
Prehistoric man & prehistoric people \\
Manned by & staffed by \\
Businessman & executive \\
Cameramen & camera operator \\
Chairman & chairperson, chair \\
Fireman & fire fighter \\
Foreman & supervisor \\
Policeman & police officer \\
Statesman & leader, politician \\
\hline
\end{tabular}

Furthermore, women and men are constructing their gender identity. Language is "the site of the culture production of gender identity" (Crawford in Stokwell, p. 160). Gender identity can be classified into two, they are:

\subsubsection{Female identity}

According to Coates in Stockwell (2006, p.160), narrative has an important role in women's life as it is a way of keeping in touch with friends. For women, updating friends on their ongoing life story is an important component in doing friendship.

With regards to male identity, men generally do not bring their addresses up to date on the story of their lives as women usually are. It means that men are more likely keeping their stories naturally. Men are usually keeping their relationship and for men, updating friends on their ongoing life story is important in keeping their relationship.

\subsubsection{Grammar}

Grammar is a study about the structure of a sentence. In grammar, people will learn about the way to create a sentence or the formulation of a sentence. "Grammar is traditionally subdivided into two different areas; they are morphology and syntax" (Radford, 2004, p.1). It means that grammar is the field where the words are combined in order to build a sentence. On the other hand grammar is known as the heart of the English learning where without grammar people are not able to know English as well. Furthermore, one of the components of the grammar is lexicon which is dictionary or list of all the lexical items or words in the language and their linguistic properties (Radford, 2004). It means that grammar has some components where lexicon is one of them which is defined as the list of words or known as lexical categories.

\subsection{Lexical Categories}

A lexical category is a syntactic category of elements that are part of lexicon of a language. These elements are at the word level. A syntactic category is a set of words and/ or phrases in a language which shares a significant number of common characteristics. The classification is based on similar structure and sameness of distribution (the structural relationships between these elements and other items in a larger grammatical structure), and not in meaning. In generative grammar, a syntactic category is symbolized by a node label in a constituent structure tree. Lexical categories may be defined in terms of core notions or prototypes. Given forms may or may not fit neatly in one of the categories. The prototype of 
any category is the member or set of members of a category that best represents the category as a whole. There are major and minor lexical categories.

\subsubsection{Noun}

A noun is a member of a syntactic class that includes words which refer to people, places, things, ideas, or concepts that include words which refer to people, places, things, ideas, or concepts whose members may act as any of the following: subjects of the verb, that define as a grammatical relation and exhibit certain independent syntactic properties. The identification of the subject relation may be further confirmed by finding significant overlap with similar subject relations previously established in other languages. Objects of the verb that defines as either a direct object or an indirect object. Indirect object of the verb, or object of a preposition (or postposition), and most of which members have inherently determined grammatical gender (in languages which inflect for gender). Nouns embody one of the most time-stable concepts in a language. As with verbs, however, this time-stability criterion defines only the prototypical nouns. Other, non-prototypical nouns must be identified by distributional similarities to prototypical nouns, such as tree, person, dog and rock. These nouns are prototypical nouns in English because they are perceived as concrete, physical, compact entities which do not change significantly over time. Words are being used to represent things and experiences in the real or imagined world. Different words can be used to describe the same thing or experience.

\subsubsection{Verb}

A verb is a member of the syntactic class of words that typically signal events and actions, constitute, singly or in a phrase, a minimal predicate in a clause, govern the number and types of other constituents which may occur in the clause, and in inflectional languages, may be inflected for tense, aspect voice, modality or aggreement with other constituents in person, number and grammatical gender. A predicate is the portion of a clause, excluding the subject that expresses something about the subject. Example; The book is on the table.

\subsubsection{Adjective}

An adjective is a word that belongs to a class whose members modify nouns. An adjective specifies the properties or attributes of a noun referent. A referent is the concrete object or concept that is designated by a word or expression. A referent is an object, action, state, relationship, or attribute in the referential realm. The referential realm is anything, real or imagined that a person may talk about. Some languages have no formally distinct category of adjectives. In such languages, property concepts are expressed as either nouns or verbs. An adjective generally occurs in a noun phrase or as a stative predicate, may be intensified, and may take comparative and superlative degrees. A noun phrase generally includes one or more modifying words, but allowance is usually made for single-word minimal noun phrases that are composed only of a noun or pronoun. Example; We will not drive the old car, She is more agile than you.

\subsubsection{Adverb}

An adverb, narrowly defined, is a word belonging to a class of words which modify verbs for such categories as time, manner, place or direction. An adverb, broadly defined, is a word belonging to a class of words which modify any constituent class of words other than nouns such as verbs, adjectives, adverbs, phrases, clauses or, sentences. Under this definition, the possible type of modification depends on the class of the constituent being 
modified. The general class adverb is a mixture of very different kinds of words, which cover a wide range of semantic concepts and whose syntactic distribution is distinctive. The definition of the lexical category adverb is language-specific, based on syntactic distribution. Many words traditionally called adverbs in English, such as degree words (very, awfully) and negatives (not), are set up as distinct word-classes in linguistic studies. Examples; She slowly shut the door, Nearly in a rage, he left.

\subsection{Previous Research}

\subsubsection{Researcher, descriptions and remark}

Nurhidayah (2014) through her qualitative study entitled "the analysis of gender differences in descriptive text written by tenth grade student of MAN 1 Batam in the academic year 2013/2014: a discourse analysis," collected her research data through questionnaires. The Results showed that men more likely describe the picture as if they were involved in the picture but women more likely describe the picture as giving the explanation what the picture telling is. Furthermore, at the end of the descriptions, women's descriptions are more likely preceded a solution rather than men. In addition, the lexical appears in the description showed men mostly used adverbs and possessive pronouns, otherwise women mostly used nouns and verbs. The title of the current research is the Analysis of gender-based writing in students' writing skill at SMA Batam in Academic 2014/2015. The current research has similarities and differences. The similarities can be seen as follows: the current research used qualitative research as those of the previous research used. Besides, the current research has similarities like approach as those of previous research. That is a Sociolinguistic approach. The differences can be seen as follows: the current research collects the data from the participants where the previous research collects the data from the internet and book.

Williams and Takaku (2011) in their research focus on gender, writing self-efficacy, and help seeking. The data were collected at the liberal arts university in Southern California and included an assessment of writing self-efficacy belief; reading scores based on the GatesMacGinitie Reading Test, Level AR; an in-house writing test; SAT verbal and writing scores; frequency of help-seeking behavior; and composition grades. The results of the his research is no gender differences with respect to writing self-efficacy belief but did show a significant gender difference with regard to writing performance. In addition, the results showed an inverse relation between writing self-efficacy and help-seeking behavior, Specifically, the international NESB students had lower self-efficacy scores than their domestic counterparts but sought help significantly more frequently. The title of the current research is the Analysis of gender-based writing in students' writing skill at SMA Batam in Academic 2014/2015. The current research has similarities and differences. Research has similarities like approach in analyzing gender and writing. Both researchers had the same method of collecting data from the book.

Jenkins and Harris (2006) researched "Gender Differences in Risk Assessment: Why do Women Take Fewer Risks than Men?" The purpose of their research is to examine some of the beliefs and preferences that underline this difference. They took the data from the 675 participants. The result of their research shows contradictory to other domains, women reported being more likely to engage in behaviors in this domain. This gender difference was partially mediated by women's more optimistic judgments of the probability of good outcomes and of outcomes being more intensely positive.

There are some similarities and differences about the title of the previous research and the current title namely "The analysis of the gender-based writing in students' writing skill. The similarities can be seen in the title of the previous research which is Gender Differences 
in Risk Assessment: Why do Women Take Fewer Risks than Men?. These two tittles have the same problem about Gender between men and women. Both researchers had the same method of collecting data from the book.

\subsubsection{Theoretical framework}

Theoretical framework gives a simple understanding about the research. Here, I also provide the theoretical framework adapted from Stockwell (2006, p. 58).

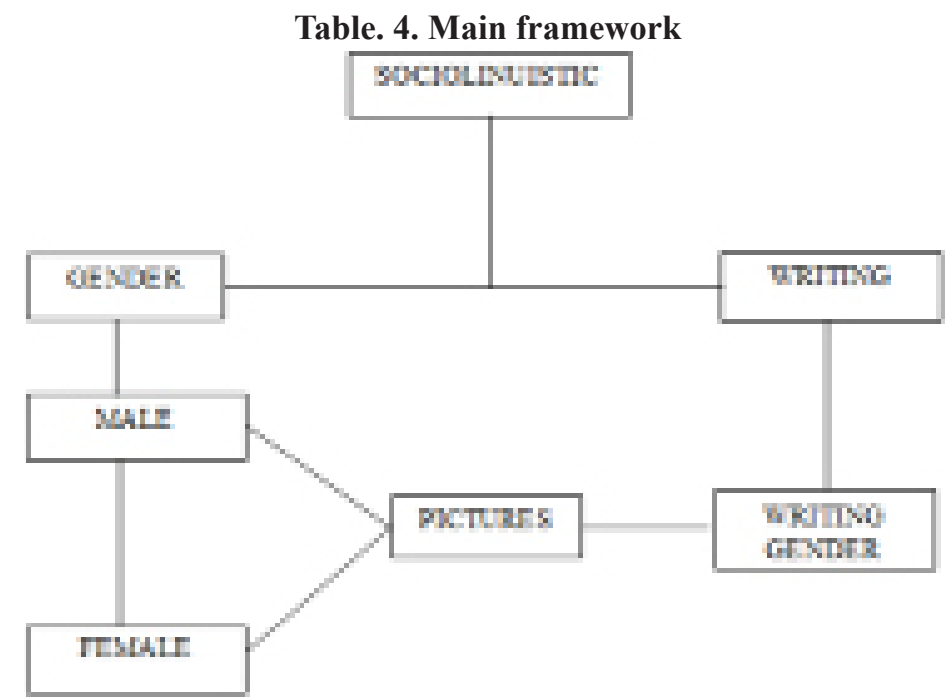

The theoretical main framework (Stockwell.2006:58)

\section{Methodology}

This research has some limitations in analyzing gender written text by using sociolinguistic approach formulated as follows; 1). Quantity of words, 2). Word classes, and 3). Characteristics of the gender in the analysis of gender-based writing in the written discourse. To find out some information to support the research problems.

Every research has a research design to prepare everything that will be needed in doing a research. This research also has a research design where research design is defined as the plan of the research before conducting a research. Research design is useful in a research in order to make the researchs goes smoothly. According to Kothari (2004, p. 14), the function of research design is to provide the collection of relevant evidences with minimal expenditure of effort, time and money. I used qualitative research in analyzing the gender-based writing in the written discourse at SMA's students at Batam. Qualitative research is a method used in order to gain or to measure the value or quality of data analysis. According to Berg (2001, p. 10), qualitative method is also important to examine the reasons that qualitative method is nonscientific the charge. I will apply this method because in this research I will describe and analyze the data by separating sentence by sentence and put them into the table. After that I will be classifying them through lexical categories and the characteristics of gender-based writing and counting the words used by the students. I collect the data by giving the picture sand asking them to describe the pictures in their own opinion.

\subsection{Population and Sample}

Every research has population and sample as the object of the research where the data are taken. Here in this research, the population and sample have been determined and the 
explanations on the object of the research are as follows; Population is the population of the data where the research is done and where the data samples are taken. Additionally, the term population is "defined as the total of items about which information is desired" (Kothari, 2006 , p. 153). The population of interest can vary widely depending on the research question and the purpose of the research. Therefore, the population of this research is the Senior High School students in Batam especially for X grade. The sample is the number of the data taken from the data population and data sample that will be used as the data to be analyzed. According to Milroy, L and Gordon, M (2003, p. 25), "the sample is drawn by some mechanical procedures such as assigning random numbers to the names on a list or selecting every individual from the frame." It means that sample is selected data from the large number of the object. Sample is the important part in the research where it is used as the main object of the research where the data analysis comes.

Furthermore, there are two types in sampling data; they are probability sampling and non-probability sampling (Kothari, 2006, p. 59-60). Non-probability sampling is a sampling procedure which does not afford any basis for estimating the probability that each item in the population has being included in the sample, while probability sampling is also known as random sampling or chance sampling. In this research, non-probability sampling will be applied as the way in sampling day where it is divided into three ways such as deliberate sampling, purposive sampling and judgment sampling (Kothari, 2006:59). From those ways, I selected judgment sampling to be apply because judgment sampling is a judgment of the respondents which arise based on the information at the research place. The respondents are chosen by the teacher to SMA's students at Batam. This article had 100 students as respondents that consisted of 50 male and 50 female students.

\subsection{Method of Collecting Data}

According to Kothari (2006, p.95), the data consists of two types; they are primary data and secondary data. In this research, the data collection called primary data, where primary data are defined as the data which are collected afresh and for the first time and thus happen to be original in character. Kothari (2006, p.96), mentions there are some methods in collecting the primary data. Questionnaire is one of the methods that I used in this research as the method in collecting the data from the respondents. The technique of collecting the data in this research is asking the students to write their opinion about the picture. I used some steps to collect the data, they were:

a. I did a pre- research. I came to the school and waited for the students out from the school then asked to write their opinion and shared the blank paper to them and collected the data in the next day because the students wrote their opinion at home. I took 100 students that consisted of 50 male students and 50 female students.

b. Asked the students to write their opinion through pictures for 15 minutes. After that I collected the paper.

As mentioned above, for the first point shows that a pre-research has been done to measure that is deserved to research. For the second point, I came back to the school and conducted the research. In conducting the research, I collected the data by using questionnaire divided into two parts. First, the research I asked the respondents to fill the questionnaire about their activities. The questionnaire is multiple-choice. Second, I asked the respondents to fill the blank paper by describing with picture. The questionnaire is in the form of essay essay. Furthermore, concerning with the second part of questionnaire about describing a 
picture, the picture tells about bad behavior of the teenagers whether they are at home and at school. I chose the theme of the picture because it was closes to the teenagers' daily life.

\subsection{Method of Analyzing Data}

In analyzing the data, there must be some steps that I did in order to make it easy to understand and logic. According to Cohen. L, Manion. L, and Morrison. $\mathrm{K}(2007: 470)$, there are several stages in analyzing data, they are (1) generating natural units of meaning, (2) classifying, categorizing and ordering these units of meaning, (3) structuring narratives to describe the contents, (4) interpreting the data. I used the stages above in analyzing the data as the guidance and the major steps in analyzing the data. In this article, I analyzed the data through some steps as follows: i). First of all, after collecting the data from the students, I scanned each of the paper that has already been filled by the students. ii). Separate sentence by sentence and put them into the table, if the word has more than one of classes of word I ignored. iii). Classifying each of words used by the students into lexical categories. iv). Classifying each of the sentence that had been written by the students into the characteristics of writing gender. v). Counting word by word written by the students vi). Giving some interpretations for each student's opinion through the picture. vii). Making conclusion from the data analysis.

The research was conducted to the students of Senior High School for 2014/2015 academic year. It is located in Batam. The schedule of the research has been arranged in order to have a good time for the students. After getting the result of the data analysis and analyzing the generic structure of descriptive text written by Senior High School students in Batam, then the data were analyzed in descriptive text based on the research formulation as follows:

\section{The Quantity of Words of Gender-Based Writing}

After analyzing the sentence and classifying each word that the respondents used in gender-based writing through 2 pictures, the table below would show the quantity of the words that I found on the respondents' gender-based writing through the pictures.

Table.5. Picture as questionnaire

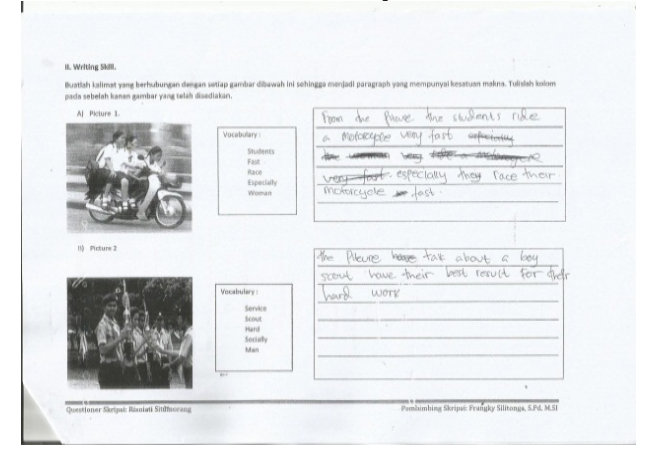

Based on the table above, it showed that the first picture and the second picture have differences about the number of the words used by the respondents in describing pictures. From the differences, the theme of the picture itself influenced the respondents to create a sentence. It can be seen from the first picture that it has bad behavior especially in riding a motorcycle. Additionally, even this country has the law or rule in riding motorcycle but the teenager in the picture ignored the rule and riding the motorcycle without helmet 
and riding motorcycle within three persons on one's motorcycle. Otherwise, the second picture was not enough to push the participants to create a sentence. Eventually, I concluded that in describing a picture he or she has to concern within the theme of the picture itself in order to get a better description and helped the people create a sentence when they draw a picture.

\section{The Characteristics of Gender-Based Writing}

The characteristics of gender-based writing that have been found in the description by seeing two : weak, vulnerable or scared and being strong, capable and logical. By showing the real data through scanning the questionnaires which have been filled by the respondents, it was classified into two of parts of the characteristic of the gender-based writing. The description of the picture of being weak, vulnerable or scared is $70 \%$

As mentioned above, by showing the picture it would help in classifying the characteristics of gender-based writing. Those pictures represent the characteristics of gender-based writing that is being weak, vulnerable and scared. The pictures represent the un-confidence of the respondents' skill. The descriptions written by the respondents showed vulnerable and scared.

\subsection{The description of the picture shows $30 \%$ strong, capable and logical}

After showing the picture where those pictures have been classified as strong, capable and logical known as the characteristics of writing gender. Those three pictures show the differences among the others where those three pictures were representing the confidence of the respondents in describing a picture. It is clear and logical.

Table.6. The Percentage of Word production (\%)

\begin{tabular}{|c|c|c|c|c|c|c|}
\hline \multirow[t]{2}{*}{ Gender } & \multirow[t]{2}{*}{ Intrument } & \multicolumn{5}{|c|}{ 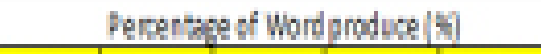 } \\
\hline & & Nen & Whit & At ptive & Aturte & Total \\
\hline \multirow{2}{*}{ Male } & Piture 1 & 593 & 5,6 & 3,4 & 68 & $\mathrm{M}_{1} \mathrm{~B}$ \\
\hline & Piture 2 & 467 & $\pi_{1} 7$ & 91 & 18.4 & Sil \\
\hline \multirow{2}{*}{ Fendt } & Pithere 1 & \$, 1 & 要 & 65 & 78 & BD \\
\hline & Pithur 2 & 95 & 2,5 & 10 & 75 & 25 \\
\hline Totol & & t510 & 로 & 7,1 & 83 & (1) \\
\hline
\end{tabular}

Therefore, by seeing all the explanation above, I identify the significance of word classes that the respondents use from the first picture and the second picture. This shows that most female students use noun, verb, adjective and adverb in describing a picture than male ones. For additional information, I also put the graphic of the percentage of words produced as explained above. 
Table. 7. Chart of Parts of Speech Production

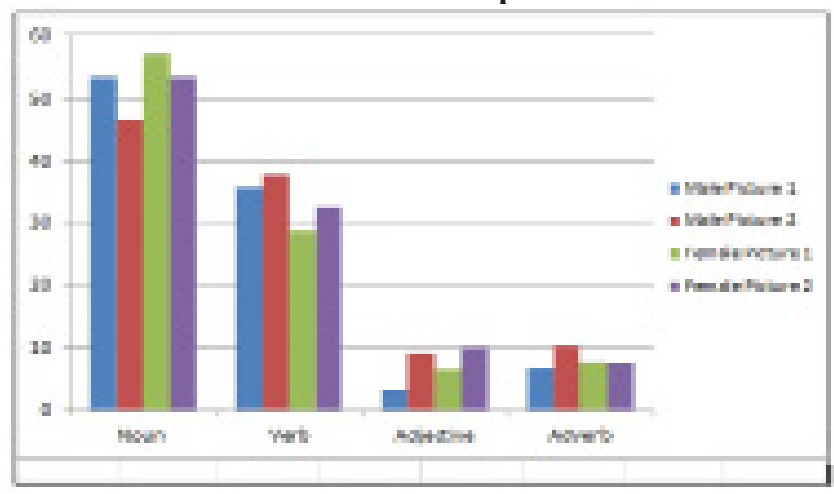

\section{Conclusion and Suggestions}

\subsection{Conclusion}

The conclusion of the research can be seen based on the results of the analysis from the previous chapter. The conclusion of this research has been formulated as follows:

a. The number of the words in writing gender by the Senior High School Students in Batam, the first picture has 1195 words and the second picture 1173 words

b. The classes of words in writing gender by Senior High School students in Batam, the first picture and the second picture, female students show that nouns were mostly used by respondents preceding verbs, adverbs and adjectives than male students.

c. The characteristics of writing gender by Senior High School students in Batamare are found $70 \%$ weak, vulnerable or scared and found 30\% strong, capable and logical found

\subsection{Suggestions}

I have some suggestions as follows:

a. The senior high school's teachers still pay attention to support the students' behavior while they were taught some subjects at school.

b. The students are given the real action of examples and good motivation from their teacher or parents.

c. The teacher's background of knowledge is required in the learning process.

d. Parental controlling is needed so that the parents are required to control the students' deeds.

\section{References}

Belmont, W \& Sharkey, M (2011:1). Grammar and Writing (Costum Edition). First Edition. The University of Newcastle

Bloomfield, L. (1973). Language. University of Chicago, London

Berg L.B.(2001).Qualitative research methods for the social Sciences. California State University, Long Beach

Cohen Louis, et al. (2007), Research Method in Educations. Sixth Edition. London and New York Department of Education Richard W. Riley, Secretary

Formkin, V., Rodman, R., \& Vina Hyams. (2011). An Introduction to Language: International Edition. Ninth Edition. Wadsworth. Canada

Kothari, C.R. (2004). Research Methodology: Methods \&Techinques. Third Edition.New 
Age International(P)Ltd. New Delhi

Milroy, L. \& Gordon M. (2003). Sociolinguistics Method and Interpretation. United State, United Kingdom, Australia, German

Pardede, H. \& Kisno. (2012). Introduction to Sociolinguistics: From General to Local Perspectives. Halaman Moeka. Jakarta - Batam

Radford, A. (2004). Minimalist Syntax: Exploring the structure of English. Cambridge

Stockwell, P. (2006). Sociolinguistic. New York

Warhaugh R. (2006). An introduction to Sociolinguistics. Fifth Edition. United Kingdom, United State, Australia.

Yule, G. (2010). The Study of Language. Fourth Edition. Cambridge University 